\title{
Characterization of the acerola industrial residues and prospection of their potential application as antioxidant dietary fiber source
}

\author{
Jéssica Silva do CARMO ${ }^{1}$, Lailla Sabrina Queiroz NAZARENO ${ }^{2}$, Maria do Socorro Moura RUFINO ${ }^{2 *}$
}

\begin{abstract}
The present work aimed to evaluate the residue generated by the processing industry of acerola juice as a natural source of nutritional compounds and dietary antioxidant fiber. The determination of the dietary fiber, extraction and determination of phenolic compounds and antioxidants associated with dietary fiber in triplicates, expressed as mean values \pm standard deviation, were performed. The pulp and refiner residues showed high contents of bioactive compounds and polyphenols, both presented high content of total dietary fiber, associated to the antioxidant activity. It is concluded that it is a material of high functional value and with beneficial health properties, being able to add value to products that have it as raw material.
\end{abstract}

Keywords: Malpighia emarginata; tropical fruits; dietary fiber; polyphenols.

Practical Application: Over the past 20 y dietary fiber (DF) has emerged as a leading dietary factor in the prevention and treatment of chronic diseases. The main characteristics of a natural product, antioxidant DF, rich in both DF and polyphenolic compounds, obtained from acerola industrial residues is described. The residues from the pulp and refiner showed a high content $(>70 \%)$, associated to the antioxidant activity, considering a material of high functional value and with beneficial health properties, being able to add value to products that have it as raw material.

\section{Introduction}

The action of the natural antioxidants present in fruits and vegetables and the relation of these with the reduction of the oxidative stress in the organism have been attracting the attention of several researchers. In recent years, several studies have been developed showing that a diet rich in natural antioxidants lowers the risk of some diseases, such as some cancers and cardiovascular diseases. Health benefits are attributed to a wide variety of food constituents such as fibers, minerals, vitamins, and other compounds (Hassimotto et al., 2005). Taking knowledge from these studies, consumers have increasingly sought to consume natural foods, arousing the interest of industries.

Acerola (Malpighia emarginata D.C.) has been prominent among these foods, mainly because of its high potential as a natural source of vitamin $\mathrm{C}$, having great economic importance in Brazil and presenting a great capacity of industrial use (Freitas et al., 2006). As a consequence of the high agricultural activity of this fruit, a large volume of agroindustrial waste is generated every year, being discarded as worthless material and often polluting the environment. Researchers have sought viable alternatives to explore the bioactive compounds of agro-industrial waste that could add value to the food, pharmaceutical and cosmetic industry (Caetano et al., 2011).

The concept of fiber and its methodology of determination have evolved greatly in recent years. Indigestible fraction is an alternative method for determination of dietary fiber developed by Saura-Calixto et al. (2000), and is based on the physiological conditions ( $\mathrm{pH}$ and temperature) that reproduce the human digestive process. This method allows the analysis of soluble and insoluble compounds that are not digested by the enzymes and reach the large intestine (Rufino, 2008).

Based on the above, this work had as objective to evaluate the residue generated by the processing industry of acerola juice as a natural source of nutritional compounds and dietary antioxidant fiber.

\section{Materials and methods}

\subsection{Obtaining the residue}

The acerola residue was supplied by the Brazilian Beverage and Food Company (EBBA), located in the city of Aracati, CE. After a previous selection, the fruits were submitted to the process of pulpy and refinement for the production of juices. The residues from these two processes were transported to the tropical fruit laboratory of the Department of Food Technology of the Federal University of Ceará (DETAL/UFC), em Fortaleza/CE, for chemical and physico-chemical characterization. The residue from the pulp, containing whole seeds, peels and a little pulp, was crushed in Philips Walita Juicer (RI 1858) multiprocessor to facilitate its homogenization. No grinding is necessary in the refining process. Samples were divided into three batches 
(replicates) and stored in a freezer at $-20^{\circ} \mathrm{C}$. In order to determine the dietary fiber (FD), the samples were transported to the Laboratory of Post-Harvest Physiology and Technology of Embrapa Agroindústria Tropical, Fortaleza, CE, where they were lyophilized in LIOTOP L202 equipment and then milled in an IKA A11 Basic mill with The purpose of reducing the particle size for the analysis.

\subsection{Chemical and physico-chemical characterization of fresh waste}

For the characterization of fresh residues, the following analyzes were carried out: $\mathrm{pH}$ in Quimis brand bench potentiometer, model 400A (Association of Official Analytical Chemistry, 1995); Total titratable acidity (TTA) using $0.1 \mathrm{M} \mathrm{NaOH}$ for the titration and phenolphthalein $1 \%$ as indicator expressing the results in percent citric acid (Instituto Adolfo Lutz, 1985); Ashes were determined using a temperature of $550{ }^{\circ} \mathrm{C}$ in muffle, Quimis brand, model 318.2, according to IAL (Instituto Adolfo Lutz, 1985); Based on the nitrogen content, determined by a digestion process followed by distillation (Tecnal distiller TE-036/1) and titration - Kjeldhal method (Association of Official Analytical Chemistry, 1995); Total soluble sugars (AST) in Shimadzu UV - 1800 spectrophotometer by the Antrona method using glucose solution as the standard solution (Loewus, 1952); vitamin C, by titration with 2,6-dichloro-phenol-indophenol $0.02 \%$ (Strohecker \& Henning, 1967) and total anthocyanins and yellow flavonoids, quantified in a spectrophotometer according to Francis (1982).

\subsection{Determination of bioactive compounds and total antioxidant activity in fresh waste}

The extracts for determination of total extractable polyphenols (PET) and total antioxidant activity (AAT) were obtained according to the methodology described by Larrauri et al. (1997) with adaptations, in an extraction with acidified methanol (50\%) and acetone (70\%). PET determination followed the method described by Obanda et al. (1997), using the Folin-Ciocalteu reagent (1:3) and the results expressed as mg of gallic acid. $100 \mathrm{~g}^{-1}$ residue. The determination of AAT followed the methodology described by Rufino et al. (2007a) by the ABTS $\bullet+$ chromophore capture method and calculated based on a linear standard curve using the 6-hydroxy-2,5,7,8-tetramethylchroman-2-carboxylic acid compound (Trolox) as the reference antioxidant. The results were expressed in $\mu \mathrm{M}$ Trolox.g-1 residue.

\subsection{Determination of dietary fiber}

The determination of dietary fiber followed the alternative method developed by Saura-Calixto et al. (2000) and according to the scheme described by Rufino et al. (2010a) in Figure 1.

The samples underwent a series of enzymatic treatments and were centrifuged, resulting in a residual fraction (insoluble food fiber - IF) and a supernatant that was subjected to an amyloglucosidase incubation and dialyzed against water, where the dialysis product is dietary fiber Solubility (FS). First, $300 \mathrm{mg}$ dry sample (dry matter - ms) was weighed and $\mathrm{HCl}-\mathrm{KCl}$ buffer solution $(0.08 \mathrm{M}, \mathrm{pH} 1.5)$ and $0.2 \mathrm{ml}$ of the enzyme pepsin (300 mg. $\mathrm{ml}^{-1}$ ), leaving incubated at $40^{\circ} \mathrm{C}$ for $1 \mathrm{~h}$. Subsequently, phosphate buffer solution (0.1 M, pH 7.5) and $1 \mathrm{~mL}$ of the enzyme pancreatin $\left(5 \mathrm{mg} \cdot \mathrm{ml}^{-1}\right)$ were added and incubated at $37^{\circ} \mathrm{C}$ for $6 \mathrm{~h}$. Then, Tris-maleate buffer solution (0.1 M, pH 6.9) and $1 \mathrm{~mL}$ of the $\alpha$-amylase enzyme $\left(120 \mathrm{mg} \cdot \mathrm{ml}^{-1}\right)$ were added and incubated at $37^{\circ} \mathrm{C}$ for $16 \mathrm{~h}$. Samples were centrifuged (Biofufe Stratos centrifuge, Heraeus Instruments) at $3000 \mathrm{rpm}$ for $15 \mathrm{~min}$ and the supernatants removed. The residual fractions from the separation were washed twice with $5 \mathrm{~mL}$ of distilled water and the supernatant of each at the end were pooled. The residues (IF) were taken to the oven and dried for $12 \mathrm{~h}$ at $105^{\circ} \mathrm{C}$ and the IF content was determined by gravimetry, as well as the Klason lignin (LK), resistant protein (PR) and ash content in this fraction. Each supernatant was incubated with sodium acetate buffer (0.4M, pH 4.75) and $100 \mu \mathrm{l}$ of the amyloglucosidase enzyme at $60{ }^{\circ} \mathrm{C}$ for $45 \mathrm{~min}$ before being transferred to dialysis bags (25.4 mm, 12-14000 daltons, INLAB, Brazil) and dialysed with the aid of a peristaltic pump (Watson Marlow brand) with

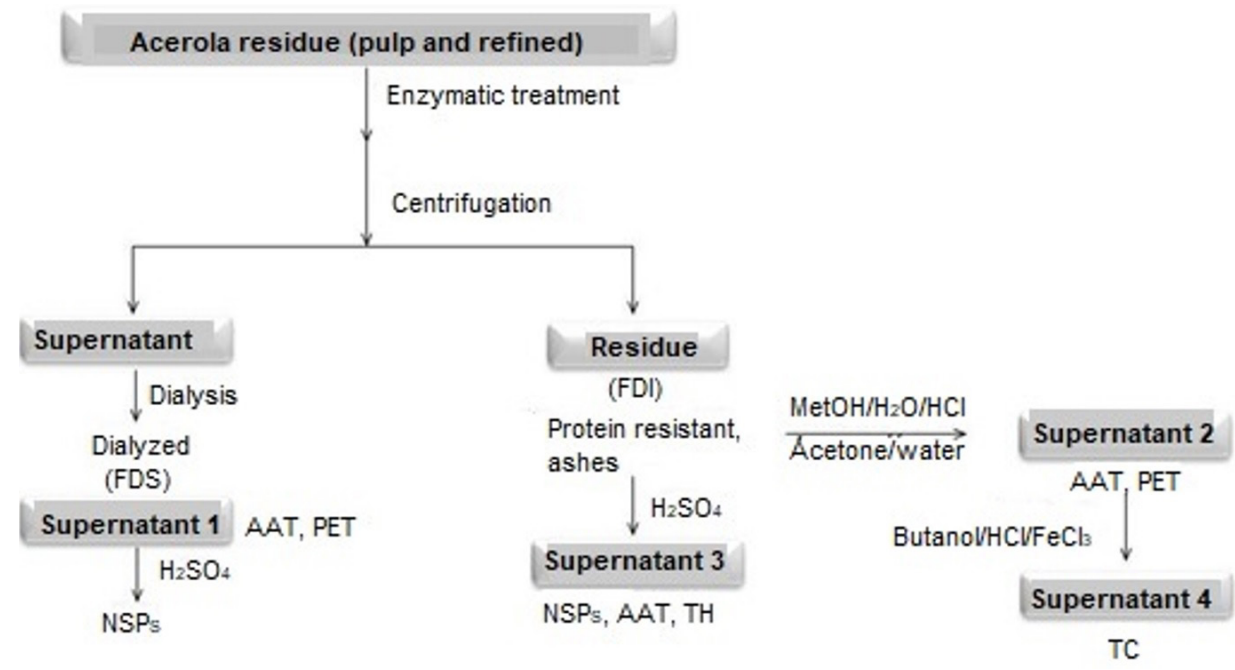

Figure 1. Schematic of determination of dietary fiber and related antioxidant activity in acerola residue. 
a flow rate of $7 \mathrm{lh}-1$ for $48 \mathrm{~h}$ at $25-28^{\circ} \mathrm{C}$ to eliminate digestible compounds, resulting in FS.

Non-starch polysaccharides (NSPs - neutral sugars and uronic acids) were determined in both soluble and insoluble fractions. FS NSPs underwent hydrolysis by taking $17 \mathrm{~mL}$ of the dialysed solution with $1 \mathrm{~mL}$ of $1 \mathrm{M}$ sulfuric acid and subjected to $100^{\circ} \mathrm{C}$ for $90 \mathrm{~min}$. The NSPs of the IF were hydrolyzed with $3 \mathrm{ml}$ of $12 \mathrm{M}$ sulfuric acid at $30^{\circ} \mathrm{C}$ for $1 \mathrm{~h}$, diluted and incubated for another $90 \mathrm{~min}$ at $100^{\circ} \mathrm{C}$, Klason lignin was determined gravimetrically from the residue of this hydrolysis. The NSPs (FS and FI) were determined by the sum of the following spectrophotometric methods: anthrone method (Loewus, 1952), dinitrosalicyclic method (Southgate et al., 1978) and uronic acids determined by the method of Scott (1979).

Total dietary fiber (FDT) was calculated as the sum of insoluble components (NSPs $+\mathrm{LK}+\mathrm{PR}+\mathrm{ash}+\mathrm{PET}$ ) plus soluble components (NSPs + PET).

\subsection{Extraction and determination of phenolic compounds and antioxidants associated with FD}

The antioxidant activity associated with soluble dietary fiber (related to extractable polyphenols) and insoluble dietary fiber (related to extractable polyphenols, hydrolysable tannins and condensed tannins) was determined.

In a part of the IF residue (material previously separated by centrifugation) extraction with acidified methanol (50\%) and acetone (70\%) was done, according to Larrauri et al. (1997) with modifications. Supernatants (Figure 1, Supernatant 2) were used to determine total antioxidant capacity by the ABTS, FRAP and DPPH methods. The residuals of this extraction were submitted to treatment with butanol/ $\mathrm{HCl} / \mathrm{FeCl} 3$ to determine condensed tannins (Figure 1, supernatant 4) (Reed et al., 1982), and the results were compared with the algaroba (Ceratonia siliqua) (Nestlé Ltd., Vers-Chez-les Blanes, Switzerland). Another part of the IF residues was subjected to extraction to obtain the hydrolysable tannins (Figure 1, supernatant 3), after acid hydrolysis already detailed in this work. The reading was carried out in a spectrophotometer at $750 \mathrm{~nm}$ and the results were expressed in g g gallic acid $\mathrm{g}^{-1}$ of m.s. (Larrauri et al., 1997). The PET of FS (Figure 1, supernatant 1) was also determined according to the Folin-Ciocalteau method (Larrauri et al., 1997) and the results were expressed in $\mathrm{g} g$ gallic acid $\mathrm{g}^{-1} \mathrm{~m} . \mathrm{s}$.

The following tests were performed to determine the total antioxidant activity associated with dietary fiber: DPPH assay - - the method described by Rufino et al. (2007b) to determine the kinetic parameters. An aliquot of $0.1 \mathrm{~mL}$ of the sample was mixed with $3.9 \mathrm{ml}$ of a solution of methanolic DPPH (60 mM), after adjusting the blank with methanol. The absorbance at $515 \mathrm{~nm}$ was measured until stabilization occurred. A calibration curve was made to calculate the EC50 and the results were expressed in g. g $^{-1}$ DPPH. Assay ABTS $\bullet+-$ the method described by Rufino et al. (2007a), the same methodology for determining the AAT of fresh residues described above. FRAP assay - the method described by Benzie \& Strain (1996) and adapted by Rufino et al. (2006).
The FRAP reagent solution was prepared at the time of analysis by adding $2.7 \mathrm{~mL}$ of this with $90 \mu \mathrm{L}$ of sample and $270 \mu \mathrm{L}$ of distilled water. The spectrophotometer was read at $595 \mathrm{~nm}$ after $30 \mathrm{~min}$. ATT was calculated using ferrous sulfate as standard and comparing at $1000 \mu \mathrm{M}$ and the results expressed in $\mu \mathrm{M}$ FeSO4. $\mathrm{g}^{-1}$ m.s.

\subsection{Other determinations}

The resistant protein content was calculated by the Kjeldhal method (Association of Official Analytical Chemistry, 1995) and the resistant gray content was determined in muffle (Quimis, model 318.2), by incinerating the material at $550{ }^{\circ} \mathrm{C}$ (Instituto Adolfo Lutz, 1985).

\subsection{Statistical analysis}

The determinations were performed in triplicate and the results were expressed as mean \pm standard deviation.

\section{Results and discussion}

In the Table 1 presents the results concerning the characterization of the acerola residue from the depolt and refining stages.

The $\mathrm{pH}$ is a parameter of low variability in acerolas, even in mature ones (Musser et al., 2004). The $\mathrm{pH}$ of the pulp and refiner residues had a mean of 3.38 and 3.43, respectively, very similar to pH 3.19 observed by Rufino et al. (2009) that analyzed the pulp of acerola, among other tropical fruits.

As for total titratable acidity, the residue from the pulp and refining presented 0.71 and $1.04 \%$ of citric acid, respectively. Sampaio et al. (2009), when analyzing the acerola clone "Roxinha" found acidity of $1.19 \%$.

The ash content of acerola residues found in this study was lower than the levels found by Lousada et al. (2006), who observed $2.68 \%$ of ash in acerola residue. The protein content found in this study was $0.60 \%$ for the pulp residue and $1.01 \%$ for the refiner, values also lower than those found by Lousada et al. (2006) in acerola residue, which was $10.54 \%$.

Table 1. Physical-chemical, chemical and total antioxidant activity of pulped and refined acerola residues ${ }^{\mathrm{a}}$.

\begin{tabular}{lcc}
\hline \multicolumn{1}{c}{ Reviews } & Waste Removal & Refining Residue \\
\hline PH & $3.38 \pm 0.05$ & $3.43 \pm 0.03$ \\
Acidity (\% citric acid) & $0.71 \pm 0.02$ & $1.04 \pm 0.01$ \\
Ashes (\%) & $0.36 \pm 0.17$ & $0.68 \pm 0.11$ \\
Proteins (\%) & $0.60 \pm 0.30$ & $1.01 \pm 0.47$ \\
Total sugars (\% glucose) & $1.93 \pm 0.07$ & $3.00 \pm 0.03$ \\
Vitamin C (mg/100g) & $175.76 \pm 1.39$ & $525.18 \pm 10.93$ \\
Total anthocyanins (mg/100g) & $19.43 \pm 1.11$ & $20.54 \pm 0.15$ \\
Yellow Flavonoids (mg/100g) & $36.56 \pm 0.54$ & $41.10 \pm 0.63$ \\
Total polyphenols & $545.98 \pm 1.13$ & $647.01 \pm 27.62$ \\
(mg gallic acid/100g) & & \\
Total antioxidant activity & $17.70 \pm 1.56$ & $20.11 \pm 4.88$ \\
( $\mu$ M Trolox/g) & & \\
\hline${ }^{a}$ Mean value \pm standard deviation, $\mathrm{n}=3$. & &
\end{tabular}


The residue from the pulp mill and the refiner showed total sugar content of 1.93 and 3.0\%, respectively. Sampaio et al. (2009) evaluating different clones of acerola found on average 3.54\% of total sugars in the pulp.

The levels of vitamin $\mathrm{C}$ found in pulp and refiner residues were 175.76 and $525.18 \mathrm{mg} \cdot 100 \mathrm{~g}^{-1}$, respectively. The values found in this study were lower than those found by Rufino et al. (2010b)

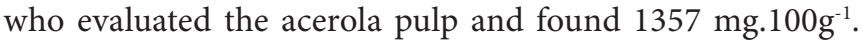
Even after the processing of acerola, its products are considered good sources of vitamin C, as long as the raw material is a good source of this vitamin. The losses will depend on the type of processing and equipment used (Maia et al., 2007).

The total anthocyanins contents observed in the pulp and refine residue were 19.43 and $20.54 \mathrm{mg} .100 \mathrm{~g}^{-1}$, respectively. These values resembled the amount found by Rufino et al. (2010b) who evaluated the acerola pulp and found $18.9 \mathrm{mg} \cdot 100 \mathrm{~g}^{-1}$ of pulp. The amount of yellow flavonoids observed in this study was much higher than the amount observed in the pulp by Rufino et al. (2010b) which was $9.6 \mathrm{mg} \cdot 100 \mathrm{~g}^{-1}$ of pulp. Several factors influence the color and other characteristics attributed to acerola quality, such as the genetic unequality of orchards, rainfall, temperature, altitude, fertilization, irrigation and the occurrence of pests and diseases (Nogueira et al., 2002).

The total extractable polyphenols were quantified and values of $545.98 \mathrm{mg}$ gallic acid. $100 \mathrm{~g}^{-1}$ were found in the residue of the pulp and $647.01 \mathrm{mg}$ gallic acid. $100 \mathrm{~g}^{-1}$ residue in the refining. Rufino et al. (2010b) when evaluating the acerola pulp found higher values $\left(1,063 \mathrm{mg} \cdot 100 \mathrm{~g}^{-1}\right)$ than that of this research.

In relation to the total antioxidant activity, the values found for the residue of the pulp were $17.70 \mu \mathrm{M}$ Trolox. $100 \mathrm{~g}^{-1}$ residue and $20.11 \mu \mathrm{M}$ Trolox.100 $\mathrm{g}^{-1}$ residue for the refining. Values higher than that of this research were reported by Rufino et al. (2010b) that evaluated the antioxidant activity by this method and found values in the fresh acerola pulp of $96.6 \mu \mathrm{M}$ of Trolox. $100 \mathrm{~g}^{-1}$ pulp.

The content and composition of the fiber in the acerola residue from the stripping and refining stages, including NSPs (neutral sugars + uronic acids), Klason lignin, resistant protein, ash and polyphenols are presented in Table 2.
The residues from the pulp and the refiner showed an FDT content of 83.50 and $77.81 \%$, respectively, of which, the largest part was FI ( $92.35 \%$ pulp and $84.96 \%$ refining). The content of FDT found in this research is above the range of values presented for some fruits (Saura-Calixto et al., 2000), such as apples, oranges or bananas, ranging from 17 to $36 \%$ (m.s.). Rufino et al. (2010a) evaluating the antioxidant dietary fiber in the acerola pulp 'BRS 236 ' and the 'CCP 76 ' clone cashew, respectively, found a content of 26 and $20.9 \%$ FDT (m.s.).

The content of Klason lignin in the pulp and refined residues was 48.85 and $32.37 \%$, respectively. Like lignin, NSPs represented a large fraction of FDT in pulp and refined residues with 29.20 and $33.81 \%$, respectively. Rufino et al. (2010a) evaluating the neutral sugars and uronic acids in the acerola pulp found in this sum $7.6 \%$ m.s. Colon bacteria are able to ferment non-digestible carbohydrates, also called prebiotics, producing compounds that are beneficial to the human organism and inhibit the multiplication of pathogens (Saad, 2006). In the FD of the depolvent and refiner residue, 1.08 and $5.88 \%$ m.s were quantified. Of resistant protein, respectively. Rufino et al. (2010a) found $2.6 \%$ m.s. In the acerola pulp and $4.1 \%$ in the cashew pulp.

The phenolic compounds and antioxidant capacity associated with FS and FI are shown in Table 3.

The content of extractable polyphenols found in pulp and refined residues related to FS was $1.04 \%$ and $1.5 \%$, and IF was $0.66 \%$ and $0.4 \%$, respectively. Rufino et al. (2010a) found in the pulp of acerola $0.96 \%$ of extractable polyphenols associated to FS and $0.36 \%$ to FI.

The content of hydrolyzable tannins associated to the DF found in the pulp and refined residues was 0.58 and $0.63 \%$. The values found here are higher than those found by Rufino et al. (2010a), which evaluated dietary fiber and associated compounds in the acerola and cashew pulp, found levels of hydrolysable tannins of 0.38 and $1.6 \%$, respectively.

The values of condensed tannins found associated with pulp and refined FD were respectively 0.31 and $0.24 \%$. In a similar work carried out by Rufino et al. (2010a) no condensed tannins associated with the FD of the acerola pulp were detected. The probable justification for this fact is related to the fact that the material evaluated in this work (bagasse) consisted of pulp,

Table 2. Contents and composition of the dietary fiber of the pulped and refined acerola residues (\% dry matter) ${ }^{\mathrm{a}}$.

\begin{tabular}{|c|c|c|c|c|c|c|}
\hline & \multicolumn{2}{|c|}{$\begin{array}{c}\text { Soluble Dietary Fiber } \\
\text { (FS) }\end{array}$} & \multicolumn{2}{|c|}{$\begin{array}{c}\text { Insoluble Dietary Fiber } \\
\text { (FI) }\end{array}$} & \multicolumn{2}{|c|}{$\begin{array}{c}\text { Total Dietary Fiber } \\
\text { (FDT) }\end{array}$} \\
\hline & Pulpy & Refin. & Pulpy & Refin. & Pulpy & Refin. \\
\hline Neutral sugars & $3.83 \pm 0.36$ & $5.55 \pm 0.87$ & $2.44 \pm 0.16$ & $2.24 \pm 0.13$ & $6.27 \pm 0.39$ & $7.79 \pm 0.87$ \\
\hline Sugars & n.d. & n.d. & $16.78 \pm 0.64$ & $17.10 \pm 1.36$ & $16.78 \pm 0.64$ & $17.10 \pm 1.36$ \\
\hline Uronic acids & $1.52 \pm 0.15$ & $4.65 \pm 0.65$ & $4.63 \pm 0.39$ & $4.27 \pm 0.45$ & $6.15 \pm 0.42$ & $8.92 \pm 0.79$ \\
\hline NSPs & $5.35 \pm 0.39$ & $10.2 \pm 1.08$ & $23.85 \pm 0.59$ & $23.61 \pm 2.07$ & $29.20 \pm 0.74$ & $33.81 \pm 3.23$ \\
\hline Lignina Klason & - & - & $48.85 \pm 1.28$ & $32.37 \pm 1.81$ & $48.85 \pm 1.28$ & $32.37 \pm 1.81$ \\
\hline Resistant protein & - & - & $1.08 \pm 0.53$ & $5.88 \pm 2.16$ & $1.08 \pm 0.53$ & $5.88 \pm 2.16$ \\
\hline Ashes & - & - & $2.67 \pm 0.18$ & $3.85 \pm 0.29$ & $2.67 \pm 0.18$ & $3.85 \pm 0.29$ \\
\hline Polyphenols & $1.04 \pm 0.08$ & $1.50 \pm 0.22$ & $0.66 \pm 0.07$ & $0.40 \pm 0.03$ & $1.70 \pm 0.11$ & $1.9 \pm 0.22$ \\
\hline Dietary fiber & $6.39 \pm 0.16$ & $11.70 \pm 1.21$ & $77.11 \pm 2.30$ & $66.11 \pm 12.31$ & $83.50 \pm 2.51$ & $77.81 \pm 18.45$ \\
\hline
\end{tabular}

NSPs: neutral sugars and uronic acids, - no analysis was performed, ${ }^{a}$ Mean value \pm standard deviation, $n=3$. n.d. non detected. 
Table 3. Polyphenols and antioxidant capacity associated with the dietary fiber of the acerola residue and refininga.

\begin{tabular}{|c|c|c|c|c|c|c|c|c|}
\hline & \multicolumn{4}{|c|}{ Soluble Dietary Fiber } & \multicolumn{4}{|c|}{ Insoluble Dietary Fiber } \\
\hline & \multicolumn{2}{|c|}{ Extractable Polyphenols } & \multicolumn{2}{|c|}{ Extractable Polyphenols } & \multicolumn{2}{|c|}{ Hydrolysable Tannins } & \multicolumn{2}{|c|}{ Condensed Tannins } \\
\hline & Pulpy & Refin. & Pulpy & Refin. & Pulpy & Refin. & Pulpy & Refin. \\
\hline Content (\% d.m.) & $1.04 \pm 0.08$ & $1.50 \pm 0.22$ & $0.66 \pm 0.07$ & $0.40 \pm 0.03$ & $0.58 \pm 0.07$ & $0.73 \pm 0.06$ & $0.31 \pm 0.06$ & $0.24 \pm 0.04$ \\
\hline $\begin{array}{c}\text { ABTS } \bullet+ \\
\left(\mu \mathrm{M} \text { Trolox g }{ }^{-1} \text { d.m. }\right)\end{array}$ & n.d. & n.d. & n.d. & n.d. & n.d. & n.d. & n.d. & n.d. \\
\hline
\end{tabular}

d.m. dry matter; n.d. not detected; N.D. not determined; ${ }^{a}$ mean value \pm standard deviation, $\mathrm{n}=3$.

bark and seed. Tannins are present in various parts of vegetables, such as leaves, roots, fruits, bark, wood, etc. However, the content and the species of tannins vary from plant to plant and plant location (Battestin et al., 2004).

In relation to the antioxidant capacity determined by the FRAP method, no antioxidant activity was detected in the extractable polyphenols associated with SF by this method, however, when analyzed the same method in the FI, the results found were $212.55 \mu \mathrm{M}$ FeSO $4 . \mathrm{g}^{-1}$ m.s. (Pulped) and $251.98 \mu \mathrm{M}$ FeSO4. $\mathrm{g}^{-1} \mathrm{~m}$.s. (Refining). The values found by this same method in the hydrolyzable tannins associated to FI presented an antioxidant activity of 343.33 and $344.84 \mu \mathrm{M} \mathrm{FeSO} 4 . \mathrm{g}^{-1} \mathrm{~m} . \mathrm{s}$. In pulp and refined waste. In a study carried out by Rufino et al. (2010a) evaluating the antioxidant capacity in the pulp of the lyophilized acerola, associated with FD by the FRAP method, using Trolox as standard, found in the extractable polyphenols of FS 51.22 $\mu \mathrm{M}$ Trolox. $\mathrm{g}^{-1}$ and in IF were found in the extractable polyphenols $14.92 \mu \mathrm{M}$ Trolox. $\mathrm{g}^{-1}$ and $8.37 \mu \mathrm{M}$ Trolox.g- 1 in the hydrolysable tannins.

In this research, the determination of the antioxidant capacity by the method of capture of the ABTS $\bullet+$ radical associated to the fiber of the acerola residues from the pulp and refining, could not be detected. Rufino et al. (2010a) also did not detect the antioxidant capacity associated with FD by this method. As for the DPPH $\bullet$ free radical capture method, the values found in this work for extractable polyphenols associated with FS in pulp and refining were 68.32 and $77.62 \mathrm{gg}^{-1} \mathrm{DPPH} \bullet$ and the IF values in both processes were 90.66 and $52.91 \mathrm{gg}^{-1} \mathrm{DPPH}$, respectively. The antioxidant capacity determined in the hydrolysable tannins by the same method was $38.7 \mathrm{~g} . \mathrm{g}^{-1} \mathrm{DPPH} \bullet$ (depolpated) and 16.94 g.g $^{-1} \mathrm{DPPH} \bullet$ (refining). In a similar work carried out by Rufino et al. (2010a) with lyophilized acerola pulp, extractable polyphenols from FS were $34.64 \mathrm{gg}^{-1} \mathrm{DPPH} \bullet, 41.91 \mathrm{gg}^{-1} \mathrm{DPPH}$ • in extractable polyphenols from FI and $262.28 \mathrm{gg}^{-1} \mathrm{DPPH} \bullet$ in hydrolyzable tannins.

\section{Conclusions}

The residues from the pulp and refiner showed high levels of bioactive compounds and polyphenols, thus contributing to a high antioxidant activity. Both presented a high content of total dietary fiber ( $>70 \%)$, associated to the antioxidant activity, considering a material of high functional value and with beneficial health properties, being able to add value to products that have it as raw material.

\section{References}

Association of Official Analytical Chemistry - AOAC. (1995). Official methods of analysis of Association of Official Analytical Chemistry (11th ed.). Washington: AOAC.

Battestin, V., Matsuda, L. K., \& Macedo, G. A. (2004). Fontes e aplicações de taninos e tanases em alimentos. Alimentos e Nutrição, 15(1), 63-72.

Benzie, I. F. F., \& Strain, J. J. (1996). The ferric reducing ability of plasma (FRAP) as a measure of antioxidant power: the FRAP assay. Analytical Biochemistry, 239(1), 70-76. http://dx.doi.org/10.1006/ abio.1996.0292. PMid:8660627.

Caetano, A. C. S., Araújo, C. R., Lima, V. L. A. G., Maciel, M. I. S., \& Melo, E. A. E. (2011). Evaluation of antioxidant activity of agro-industrial waste of acerola (Malpighia emarginata D.C.) fruit extracts. Food Science and Technology, 31(3), 769-775. http://dx.doi.org/10.1590/ S0101-20612011000300034.

Francis, F. J. (1982). Analysis of anthocyanins. In P. Markakis (Ed.), Anthocyanins as food colors (pp. 181-207). New York: Academic Press. http://dx.doi.org/10.1016/B978-0-12-472550-8.50011-1.

Freitas, C. A. S., Maia, G. A., Costa, J. M. C., Figueiredo, R. W., \& Sousa, P. H. M. (2006). Acerola: produção, composição, aspectos nutricionais e produtos. Revista Brasileira de Agrociência, 12(4), 395-400.

Hassimotto, N. M. A., Genovese, M. I., \& Lajolo, F. M. (2005). Antioxidant activity of dietary vegetables, fruits and commercial frozen fruits pulp. Journal of Agricultural and Food Chemistry, 53(8), 2928-2935. http://dx.doi.org/10.1021/jf047894h. PMid:15826041.

Instituto Adolfo Lutz - IAL. (1985). Normas analíticas Instituto Adolfo Lutz. (3 ed., Vol. 1, 533 p.). São Paulo: IAL.

Larrauri, J. A., Rupérez, P., \& Saura-Calixto, F. (1997). Effect of drying temperature on the stability of polyphenols and antioxidant activity of red grape pomace peels. Journal of Agricultural and Food Chemistry, 45(10), 1390-1393. http://dx.doi.org/10.1021/jf960282f.

Loewus, F. A. (1952). Improvement in the anthrone method for determination of carbohydrates. Analytical Chemistry, 24(1), 219. http://dx.doi.org/10.1021/ac60061a050.

Lousada, J. E. Jr., Costa, J. M. C., Neiva, J. N. M., \& Rodriguez, N. M. (2006). Caracterização físico-química de subprodutos obtidos do processamento de frutas tropicais visando seu aproveitamento na alimentação animal. Revista Ciência Agronômica, 37(1), 70-76.

Maia, G. A., Sousa, P. H. M., Santos, G. M., Silva, D. S., Fernandes, A. G., \& Prado, G. M. (2007). Efeito do processamento sobre componentes do suco de acerola. Food Science and Technology, 27(1), 130-134. http://dx.doi.org/10.1590/S0101-20612007000100023. 
Musser, R. S., Lemos, M. A., Lima, V. L. A. G., Mélo, E. A., Lederman, I. E., \& Santos, V. F. (2004). Características físico-químicas de acerola do banco ativo de germoplasma em Pernambuco. Food Science and Technology, 24(4), 556-561. http://dx.doi.org/10.1590/ S0101-20612004000400013.

Nogueira, R. J. M. C., Moraes, J. A. P. V., Burity, H. A., \& Silva Junior, J. F. (2002). Efeito do estádio de maturação dos frutos nas características físico-químicas de acerola. Pesquisa Agropecuária Brasileira, 37(4), 463-470. http://dx.doi.org/10.1590/S0100-204X2002000400006.

Obanda, M., Owuor, P. O., \& Taylor, S. J. (1997). Flavonol composition and caffeine content of green leaf as quality potential indicators of Kenyan black teas. Journal of the Science of Food and Agriculture, 74(2), 209-215. http://dx.doi.org/10.1002/(SICI)1097-0010(199706)74:2<209::AIDJSFA789>3.0.CO;2-4.

Reed, J. D., Mcdowell, R. T. E., Van Soest, P. J., \& Horvath, P. R. J. (1982). Condensed tannins: a factor limiting the use of cassava forage. Journal of the Science of Food and Agriculture, 33(3), 213-220. http://dx.doi. org/10.1002/jsfa.2740330302.

Rufino, M. S. M. (2008). Propriedades funcionais de frutas tropicais brasileiras não tradicionais (Tese de doutorado). Universidade Federal Rural do Semiárido, Mossoró.

Rufino, M. S. M., Alves, R. E., Brito, E. S., Morais, S. M., Sampaio, C. G., Pérez-Jiménez, J., \& Saura-Calixto, F. (2006). Metodologia científica: determinação da atividade antioxidante em frutas pelo método de redução do ferro (FRAP). (Comunicado Técnico, $\mathrm{n}^{\circ}$ 125). Fortaleza: Embrapa Agroindústria Tropical.

Rufino, M. S. M., Alves, R. E., Brito, E. S., Morais, S. M., Sampaio, C. G., Pérez-Jiménez, J., \& Saura-Calixto, F. (2007a). Metodologia científica: determinação da atividade antioxidante em frutas pela captura do radical livre ABTS $\bullet$. (Comunicado Técnico, $\mathrm{n}^{\circ} 128$ ). Fortaleza: Embrapa Agroindústria Tropical.

Rufino, M. S. M., Alves, R. E., Brito, E. S., Morais, S. M., Sampaio, C. G., Pérez-Jiménez, J., \& Saura-Calixto, F. (2007b). Metodologia científica: determinação da atividade antioxidante total em frutas pela captura do radical livre DPPH. (Comunicado Técnico, $\mathrm{n}^{\circ} 127$ ). Fortaleza: Embrapa Agroindústria Tropical.
Rufino, M. S. M., Alves, R. E., Brito, E. S., Silveira, M. R. S., \& Moura, C. F. H. (2009). Quality for fresh consumption and processing of some non-traditional tropical fruits from Brazil. Fruits, 64(6), 361370. http://dx.doi.org/10.1051/fruits/2009032.

Rufino, M. S. M., Pérez-Jiménez, J., Tabernero, M., Alves, R. E., Brito, E. S., \& Saura-Calixto, F. (2010a). Acerola and cashew apple as sources of antioxidants and dietery fibre. International Journal of Food Science \& Technology, 45(11), 2227-2233. http://dx.doi. org/10.1111/j.1365-2621.2010.02394.x.

Rufino, M. S. M., Alves, R. E., Brito, E. S., Pérez-Jiménez, J., SauraCalixto, F., \& Mancini-Filho, J. (2010b). Bioactive compounds and antioxidant capacities of 18 non-traditional tropical fruits from Brazil. Food Chemistry, 121(4), 996-1002. http://dx.doi.org/10.1016/j. foodchem.2010.01.037.

Saad, S. M. I. (2006). Probióticos e prebióticos: o estado da arte. Revista Brasileira de Ciências Farmacêuticas, 429(1), 1-16. http://dx.doi. org/10.1590/S1516-93322006000100002.

Sampaio, C. G., Morais, S. M., Rufino, M. S. M., Alves, R. E., \& Brito, E. S. (2009). Quality, bioactive compound content, and antioxidant activity in fruits of brazilian acerola clones. Acta Horticulturae, 841(841), 463-466. http://dx.doi.org/10.17660/ActaHortic.2009.841.59.

Saura-Calixto, F., García-Alonso, A., Goñi, I., \& Bravo, L. (2000). In vitro determination of the indigestible fraction in foods: an alternative to dietary fiber analysis. Journal of Agricultural and Food Chemistry, 48(8), 3342-3347. http://dx.doi.org/10.1021/jf0000373. PMid:10956113.

Scott, R. W. (1979). Colorimetric determination of hexuronic acids in plant materials. Analytical Chemistry, 51(7), 936-940. http://dx.doi. org/10.1021/ac50043a036.

Southgate, D. A. T., Hudson, G. J., \& Englyst, H. (1978). The analysis of dietary fibre-the choices for the analyst. Journal of the Science of Food and Agriculture, 29(11), 979-988. http://dx.doi.org/10.1002/ jsfa.2740291113.

Strohecker, R., \& Henning, H. M. (1967). Análisis de vitaminas: métodos comprobados (pp. 428). Madrid: Paz Montalvo. 